\title{
Plant invasion as an emerging challenge for the conservation of heritage sites: the spread of ornamental trees on ancient monuments in Rome, Italy
}

\author{
Laura Celesti-Grapow (D) Carlo Ricotta $(\mathbb{D}$
}

Received: 30 June 2020/Accepted: 23 November 2020/Published online: 5 December 2020

(C) The Author(s) 2020

\begin{abstract}
Cultural heritage sites such as historical or sacred areas provide suitable habitats for plants and play an important role in nature conservation, particularly in human-modified contexts such as urban environments. However, such sites also provide opportunities for the spread of invasive species, whose impact on monuments has been raising growing concerns. The aim of this study was to investigate the patterns of distribution and spread of invasive plants in heritage areas, taking the city of Rome as an example. We focused on woody species as they pose the greatest threat to the conservation of monuments, owing to the detrimental effects of their root system. We analysed changes in the diversity and traits of native and non-native flora growing on the walls of 26 ancient sites that have been surveyed repeatedly since the 1940s. We found that the diversity of the native flora has steadily decreased, while there has been an increase in non-native, larger and more damaging species. The introduced species that have expanded most are ornamental wind- or bird-dispersed trees, which represent a major management problem as their propagules can reach the upper sections of the monuments, where they become more difficult to control. The most widespread and damaging of such species is Ailanthus altissima, which has recently been
\end{abstract}

L. Celesti-Grapow $(\square) \cdot$ C. Ricotta

Department of Environmental Biology, Sapienza University, Piazzale Moro, 5, 00185 Rome, Italy

e-mail: laura.celesti@uniroma1.it included among the invasive species of European Union concern (EU Regulation 2019/1262). Our findings show that plant invasion is an emerging challenge for the conservation of heritage sites and needs to be prioritized for management to prevent future expansion.

Keywords Ailanthus altissima - Biodeterioration · EU regulation on invasive alien species - Impacts . Ornamental horticulture $\cdot$ Urban flora

\section{Introduction}

Culturally protected sites, such as monumental or sacred sites, play an important role in nature conservation throughout the world (Bhagwat and Rutte 2006; Verschuuren et al. 2010; Gao et al. 2013; Frascaroli et al. 2016; Woods et al. 2017), particularly when they are located in environments that have been markedly modified by man, such as agricultural landscapes (Frosch and Deil 2011). In cities, they are even more crucial (Jackson and Ormsby 2017) because they become part of a network of green spaces such as parks (Nielsen et al. 2014) and road verges (Rupprecht and Byrne 2014; Säumel et al. 2016) that can deliver numerous ecosystem services and play a key role in the conservation of urban biodiversity (Shwartz et al. 2014; Kowarik et al. 2016; Planchuelo et al. 2019). 
Numerous cities throughout the world contain cultural heritage sites that have been protected from urban development and have become important components of the urban green infrastructure (Gopal et al. 2019). The reasons for protecting these cultural areas vary according to the specific value of the site, which depends on whether they are of historic, artistic or religious importance. However, as the expansion and densification of cities continue, these areas are becoming increasingly valuable on account of their habitat and biodiversity functions. Larger sites can, owing to their size, heterogeneity and moderate human-mediated disturbance, provide key habitat for a wide range of plants and wildlife, and therefore harbour a rich diversity of species, which often even exceed that found in more intact natural elements of the urban green, such as remnant forests and urban parks (Kowarik et al. 2016). Since parts of these structures, such as the tops of high monuments and walls, are difficult and expensive to access to man, some sites also provide a refuge for relict populations of species of high conservation value, which have become rare in the surrounding rural environments (Shwartz et al. 2014; Ives et al. 2016). Smaller sites also form a key part of the urban green infrastructure and enhance biodiversity by creating a series of green patches in the urban mosaic or by providing habitat continuity and improving connectivity within the urban ecological network when they stretch over considerable distances in built-up areas, as in the case of ancient city walls (Shwartz et al. 2013).

On account of this connectivity and of their vicinity to propagule sources and human-mediated disturbance, urban heritage sites also provide opportunities for the establishment and spread of invasive plants. Until recently this was not considered to be a significant economic or environmental problem because the majority of the non-native species that grow spontaneously within heritage areas tend to be confined to the most disturbed habitats, such as trampled areas and paths, which have a low conservation value and are successfully controlled by means of ordinary mowing and clearing procedures (CelestiGrapow and Blasi 2004; Cicinelli et al. 2018). However, when they grow on, or close to monuments, introduced plants can, like native plants, seriously threaten their conservation (Caneva et al. 2006; Cicinelli et al. 2020). In fact, vascular plants can inflict severe damage on buildings and structures, largely due to their roots, which induce both chemical and mechanical forms of deterioration (Cutler and Richardson 1989; Caneva et al. 2008). Moreover, the recent acceleration of biological invasions in a wide range of habitats worldwide (Seebens et al. 2017), particularly in urban and human-made habitats, where invasion success is facilitated by high levels of disturbance and the high-intensity planting of introduced species (Pyšek et al. 2010a, 2010b; Kowarik 2011; Gaertner et al. 2016; Cadotte et al. 2017; Kühn et al. 2017) has also affected heritage sites, and the spread and impact of some species on monuments has become a source of increasing concern (Caneva et al. 2009; Casella and Vurro 2013; Minissale and Sciandrello 2017).

Rome, one of the largest and most populated cities in southern Europe, represents an ideal case study to investigate these issues because it has an exceptionally long history of plant species introductions and a rich body of botanical documentation, which spans the last four centuries and is often focused on the flora of ancient sites. Although introduced plants have been considered to play a very minor role in the flora of these sites, the expansion and impact of some invasive species in recent decades has increasingly threatened their conservation.

A number of studies have been conducted on the impact of other taxonomic groups, such as fungi, lichens and bryophytes, on the biodeterioration of stone monuments (Salvadori and Casanova 2016; Warscheid and Braams 2000) and advances have been made in our knowledge of the plant cover of archaeological areas (Ceschin et al. 2016) particularly of the most noxious native species, such as ivy (Hedera helix L., Bartoli et al. 2017). However, a gap in research on non-native flora growing in heritage sites remains. Specific studies are needed to shed more light on this emerging trend and to implement effective management strategies.

As a contribution to this little-investigated field of research, we studied the vascular flora growing on the ancient walls of Rome to analyze trends in the patterns of native and non-native plant species richness and spread in heritage sites over time. We focused on woody species because they are among the main plant invaders worldwide (Richardson and Rejmánek 2011; van Wilgen and Richardson 2014), they are considered the most harmful invasive species in urban systems (Potgieter et al 2017) and they pose the greatest threat 
to the conservation of monuments, whether they grow on them or in their vicinity, owing to the detrimental effects of their extended root system (Lisci et al. 2003; Motti and Stinca 2011).

Here we present an analysis of the woody flora growing on the walls of ancient sites in Rome that have been surveyed repeatedly since the mid-1940s. We aimed to explore changes in native and non-native flora richness and traits such as size and growth form, which are key components in determining the damage potential of the species and, consequently, their potential impact on monuments. We also aimed to investigate the introduction history and dispersal strategies of non-native species as drivers of invasion success, as well as to identify the major invasive species, i.e. those that have changed most and those that are currently most widespread on the monuments.

\section{Materials and methods}

Study area

We analysed the vascular flora recorded on the walls of 26 heritage sites in the city of Rome, Italy.

The Rome metropolitan region, which is located in the centre of the Mediterranean $\left(41^{\circ} 54^{\prime} \mathrm{N}, 12^{\circ} 29^{\prime} \mathrm{E}\right)$, has a population of $2,750,000$ inhabitants within an area of $1287 \mathrm{~km}^{2}$. The urban area covers approximately $345 \mathrm{~km}^{2}$ and is enclosed in a suburban matrix of agricultural, semi-natural and built-up areas (Capotorti et al. 2013).

The climate is sub-Mediterranean and the natural vegetation consists of deciduous or mixed oak woodland. The current landscape is very heterogenous owing to the natural lithomorphological complexity of the area and to the long history of human impact, which spans almost three millennia and has produced a large variety of habitats and vegetation types. The Rome metropolitan region contains a rich flora that consists of 1649 species, the majority of which $(86.2 \%)$ are native to Italy while the remainder $(13.8 \%)$ are introduced species (Celesti-Grapow et al. 2013). Approximately 1300 species, $15 \%$ of which are woody, occur in the urban area, which is characterized by a high richness of tree and shrub species from natural vegetation, that grow spontaneously, prevalently in patches of natural forests and in man-made parks in the vicinity of the city centre.
Innumerable heritage sites of outstanding arthistorical and archaeological significance are scattered throughout the metropolitan area of Rome. Some major sites (e.g. the Colosseum, the Caracalla Baths and the Roman Forum) cover large areas, other remains are very small, but still of outstanding arthistorical and archaeological importance, such as fragments of walls dating back to the sixth century BC.

Owing to their high degree of environmental heterogeneity and to different management practices, these sites support a rich diversity of wild, mainly native, plants (Ceschin et al. 2016). Ancient walls are the most common host environment of the flora in these sites. These walls often support a greater abundance of plants than any other area in the heritage site, largely because they are the parts from which it is most difficult to remove vegetation. Plants colonise a variety of habitats provided by the vertical walls and horizontal tops of the sites, with highly diverse ecological conditions resulting from differences in factors such as inclination, exposure, moisture, building materials, age of the construction and type of management (Lisci and Pacini 1993).

In recent centuries, the heritage sites in Rome have been subjected to increasingly intense management efforts aimed at clearing the plant cover. After having been in a state of abandonment and covered by large amounts of vegetation for hundreds of years, preservation and restoration efforts gradually began in the early nineteenth century and increased in the twentieth century, becoming increasingly intense in the last decades (Caneva et al. 2003). The sites are now periodically managed by removing the vegetation cover, largely by means of mechanical weed control methods based on mowing. Weeding operations are generic actions that do not distinguish between invasive species and non-invasive species; specific actions targeted at invasive species are not carried out. The frequency of weeding operations varies greatly depending on the sites. In some major tourist areas they take place on a weekly basis in the peak growing season (April-July) so to allow the visitors to have an unimpeded view of the sights. In other sites, such as in those containing ancient walls, they are carried out far less frequently and for reasons such as safety, e.g. owing to the risk of falling branches or because road signs have been covered by the vegetation (SABAP 2020). 
The total removal of all deteriogen agents (i.e. any agents that result in the deterioration of man-made constructions), including mosses and lichens, is infrequent owing to the high costs involved, and problems related, among other things, to the use of specific chemicals designed not to damage the sites, as well as to the difficulties encountered in reaching the highest parts of the monuments (Caneva et al. 2008). The number of more thorough interventions has increased in the last two decades thanks to the organization of special cultural events in Rome that have provided the financial support required to carry them out.

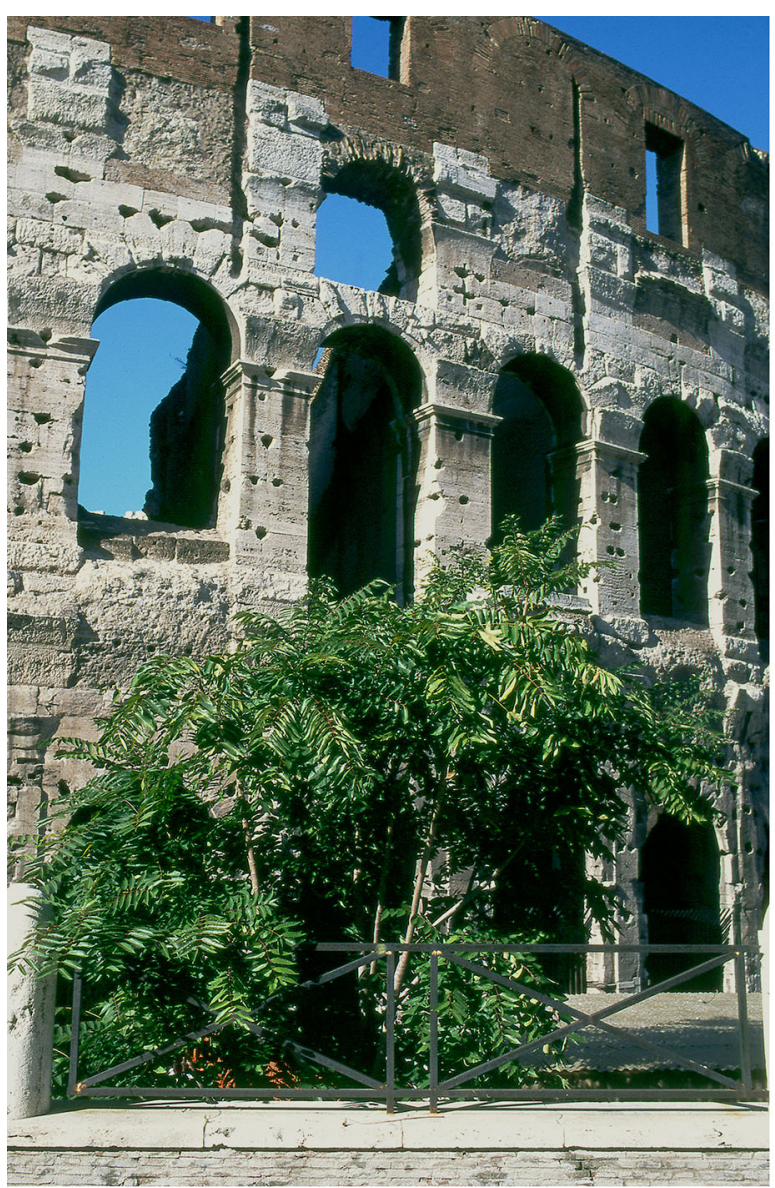

Fig. 1 Examples of the sites and of the plants studied in the historic centre of Rome, Italy. The invasive tree Ailanthus altissima growing close to the Colosseum (left). The native shrub Capparis spinosa, growing on the remaining arch of the
Selection of the sites and data survey

All the selected sites are located in the historic centre of Rome, which has been included among the UNESCO world heritage sites on account of its outstanding artistic value (WHC UNESCO 1990). The sites, which are integrated within the urban fabric, include some archaeological remains of great importance, such as the Colosseum, fortifications built over the centuries (e.g. city walls dating from different periods), a monumental cemetery and some old religious buildings associated with the Vatican City (Fig. 1).

The 26 sites were chosen from a larger sample of 40 sites surveyed by the Roman botanist Anzalone (1951) after the Second World War, between 1946 and 1950.

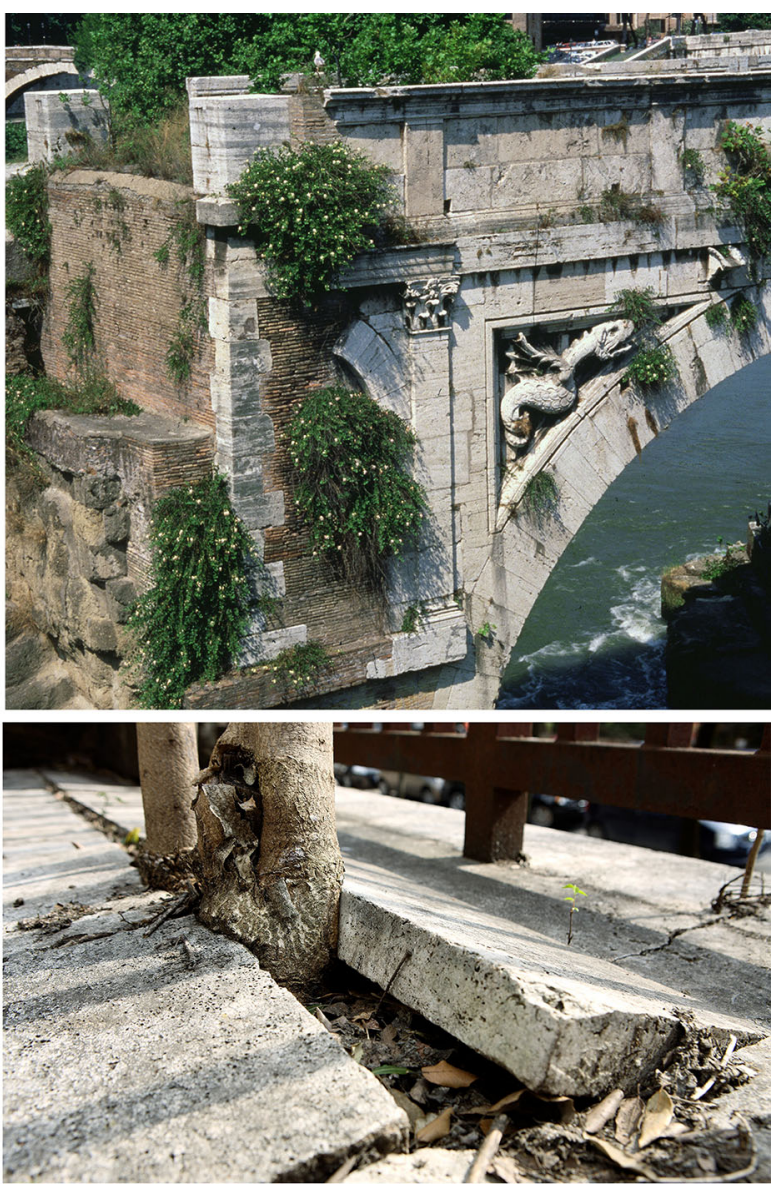

Pons Aemilius, the oldest Roman stone bridge on the river Tiber (top right). Damage inflicted to heritage sites by the roots of Ailanthus altissima (bottom right). Photographed by J. Grapow 
We surveyed the same sites three times in 1988-1990, 1994-1995 and 2004-2005 (hereafter referred to as 1990, 1995 and 2005) within different research projects that were either specifically dedicated to the flora of archaeological sites or to the overall urban flora of Rome (Celesti-Grapow 1995; Celesti-Grapow et al. 2006, 2013), often by exploiting platforms and scaffolding being used for restoration purposes that allowed us to study areas that cannot normally be accessed. The different sites were surveyed with the same sampling procedure as that used by Anzalone (1951) and at least once in each of the main vegetative seasons of the flora of Rome, i.e. spring/early season (March-April), spring/summer main season (May to July) and summer/autumn late season (September to October).

Like Anzalone (1951), we only recorded the flora growing on the monuments (i.e. on the vertical walls and tops) or at their base. We used occurrence records as they represent the first essential piece of information for monitoring invasive species, particularly their range expansion (Latombe et al. 2017).

We surveyed the same sites, using the same sampling procedure, a fourth time during the spring of 2016-2019. Of the 40 sites first investigated by Anzalone (1951), we excluded from our most recent survey (hereafter referred to as 2019) those sites that are located outside the city centre because the land use and level of urbanization in their immediate surroundings have greatly changed over the decades. This has led to a deep transformation of the sites, which means they cannot be detected accurately or be surveyed by means of the same sampling methods, which is essential if comparisons are to be made between the past and present situations. By contrast, the city centre, which has been densely built-up and almost continually inhabited for more than two millennia, has not undergone such marked rural-to-urban transformations since the time of Anzalone's surveys.

We also excluded some sites that could no longer be accessed closely enough to be able to survey their flora. Other sites had already been excluded from our previous surveys conducted between 1988 and 2005 as their location could not be clearly identified on the basis of the original description provided by Anzalone (1951).
Compilation of the dataset

We compiled a dataset of the woody flora, containing the presence and absence scores of all woody species (i.e. including both phanerophytes and chamaephytes according to Raunkiaer's 1905 system of classification of life forms), recorded in the 26 historical sites from Anzalone (1951) and from our own survey campaigns (1990, 1995, 2005 and 2019). As mentioned earlier, we concentrated on woody species not only because they are considered among the most harmful invasive plants worldwide (van Wilgen and Richardson 2014), but, above all, because they are the species that inflict by far the most damage on human constructions such as buildings, walls and monuments owing to the large size and secondary diametric growth of the roots (Lisci et al. 2003; Motti and Stinca 2011).

For each species, we provided information (1) on plant form, i.e. tree, shrub, dwarf shrub (the latter including Raunkiaer's (1905) life forms chamaephytes and nanophanerophytes) or vine as it is considered to be related to the potential damaging capacity of the plants, with trees being the most damaging species and dwarf shrubs the least (Signorini 1996; Caneva et al. 2008; Motti and Stinca 2011), and (2) on the height of the species as a proxy for the size of the plant, as larger plants are considered to cause the most severe damage on human artifacts owing above all to their more extended root systems and greater weight (Caneva et al. 2006). These data were gathered from the flora of Italy (Pignatti 2017-2019). We also provided each species with (3) the Hazard Index (HI), with values ranging from 0 to 10 . This index, which is attributed to vascular species on the basis of (i) life form (ii) invasiveness and vigour and (iii) capacity of vegetative reproduction and type of root system, is used to estimate the potential of a species to damage buildings (for details, see Signorini 1996; Motti and Stinca 2011; Motti and Bonanomi 2018).

To analyse the spread of invasive species, for the non-native flora we added the information on dispersal strategies and introduction pathways, which is crucial for the management of plant invasions (Pergl et al 2017; Sádlo et al. 2018). Therefore, for each nonnative species, we also used the database of the flora of Rome (Celesti-Grapow 1995) to extract some additional information on: 
(1) Main dispersal mode, referring to transport of diaspores by different vectors (Kleyer et al. 2008; Pérez-Harguindeguy et al. 2013; Sádlo et al. 2018), divided according to the following categories: autochory (self-dispersal), dispersal by birds, by humans, by insects, by mammals, by water and by wind.

(2) Pathway of introduction. A general framework for classifying introduction pathways of alien species has been developed by Hulme et al. (2008) and implemented by the UN Convention on Biological Diversity (CBD 2014). In our study, we classified the species according to their pathway of introduction in Italy and adopted the following subcategories (we use here the original names of the categories, for details on the framework and its categories see Hulme et al. 2008; CBD 2014): erosion control such as windbreaks and hedges; landscape improvement in the wild (within the release category); agriculture, botanical garden, forestry, horticulture, ornamental purpose other than horticulture (within the escape category); contaminant of nursery material and seed contaminant (within the contaminant category).

Data analysis

For the 26 sites used in this study, we separately tested for compositional differences in the native and nonnative flora between the five sampling dates (1950, 1990, 1995, 2005 and 2019) using one-way nonparametric multivariate analysis of variance (PERMANOVA; Anderson 2001; McArdle and Anderson 2001) and the Jaccard dissimilarity coefficient for presence and absence data.

All calculations were performed using the program PAST (freely available at: http://folk.uio.no/ ohammer/past) and 9999 permutations. To visualize changes in the floristic composition of the native and non-native flora between the five sampling dates, we applied a principal coordinate analysis (PCoA) to the Jaccard dissimilarities between sampling units (see Legendre and Legendre 1998).

For each of the 130 sampling units (i.e. 26 sites $\times 5$ sampling dates), we calculated the mean value of the hazard index and the maximum plant height by averaging the values of all species present in each sampling unit. We also calculated, for each sampling unit, the proportion of species (native or non-native) belonging to the four plant forms: tree, shrub, dwarf shrub or vine. For the non-native flora we also added the proportion of non-native species belonging to the different introduction pathways and dispersal modes used in this study. For all these quantitative variables, we separately tested for differences between the five sampling dates using traditional one-way ANOVA and 9999 permutations.

\section{Results}

A total of 119 woody species, 35 (29.4\%) of which are non-native, were detected on the walls of the 26 heritage sites in all 5 samplings from 1951 to 2019; 27 of these species are trees, 55 shrubs, 20 dwarf shrubs and 17 vines. The current wall flora of the 26 sites (2019 survey) contains 84 woody species, 35 (41.7\%) of which are non-native. The number of species in the flora varies considerably from site to site; the richest is the Palatine hill, where a total of 34 woody species were recorded in the latest survey (2019). All the recorded non-native species escaped from cultivation; the majority of these (19 species) were introduced for ornamental purposes.

Although the overall richness remains substantially unchanged, as shown in Table 1 and Fig. 2, the floristic composition of both the native and non-native species groups significantly changed across the sampling dates, with a substantial decrease in native species (533 occurrences in 1950 vs. 216 in 2019) and a corresponding increase in non-native species (30 occurrences in 1950 vs. 224 in 2019). The non-native species whose numbers increased most are: Acer negundo L. (1 occurrence in 1950 vs. 16 in 2019), Ailanthus altissima (Mill.) Swingle (5 vs. 22), Ligustrum lucidum W.T.Aiton (1 vs. 15), Lonicera japonica Thunb. (2 vs. 11), Parthenocissus quinquefolia (L.) Planch. (2 vs. 15), Platanus hispanica Mill. ex Münchh. (0 vs. 12) and Robinia pseudoacacia L. (3 vs. 16); these are also the species that are currently most widespread in the 26 sites.

The results of traditional one-way ANOVA further showed that the mean sample values for plant height ( $F=16.63, \quad p<0.0001 ; 9999$ permutations), the hazard index $(F=20.17, p<0.0001)$ and the relative proportion of trees $(F=25.75, \quad p<0.0001)$ 
Table $1 P$-values of the pairwise tests for compositional differences in the native flora (above, white cells; overall $F$ statistic $=1.876, p=0.0002$ ) and non-native flora (below, grey cells; $F=2.659, p<0.0001$ ) between the five sampling dates

\begin{tabular}{|c|c|c|c|c|c|c|}
\hline & & \multicolumn{5}{|c|}{ Native flora } \\
\hline & & 1950 & 1990 & 1995 & 2005 & 2019 \\
\hline \multirow[t]{5}{*}{ Non-native flora } & 1950 & & 0.6219 & 0.0708 & 0.0002 & 0.0001 \\
\hline & 1990 & 0.0597 & & 0.9986 & 0.2468 & 0.0017 \\
\hline & 1995 & 0.0007 & 0.9956 & & 0.8378 & 0.0235 \\
\hline & 2005 & 0.0001 & 0.0102 & 0.2232 & & 0.5321 \\
\hline & 2019 & 0.0001 & 0.0001 & 0.0002 & 0.8733 & \\
\hline
\end{tabular}

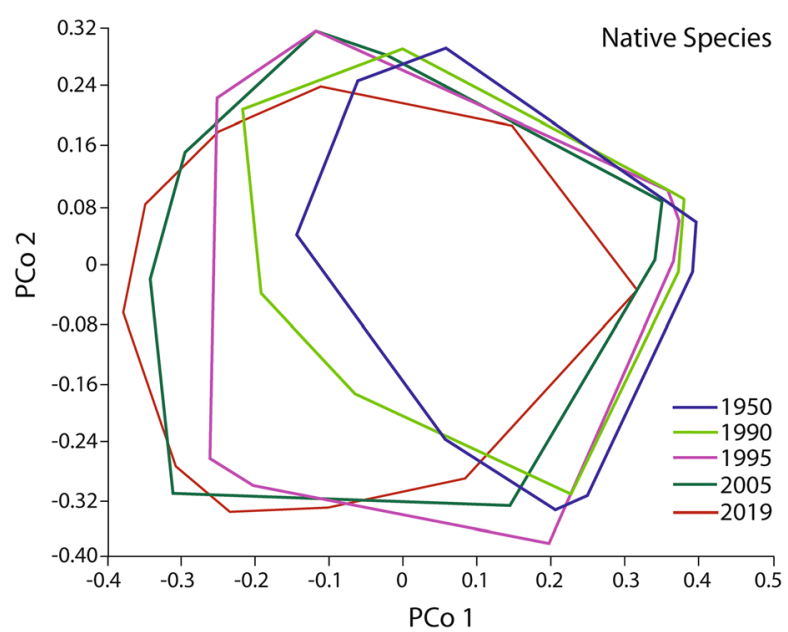

Fig. 2 Two-dimensional principal coordinate analysis (PCoA) of the 130 sampling units (i.e. 26 sites $\times 5$ sampling dates) analysed in this study showing the convex hulls of the five

significantly increased over time, whereas the relative proportion of shrubs $(F=4.51, p<0.0018)$ significantly decreased (Table 2). By contrast, the proportions of the remaining plant life forms did not differ significantly between the different sampling dates at $p<0.05$.

When non-native species alone were considered, the analysis of variance highlighted a significant increase in the relative proportion of species introduced for ornamental purposes $(F=9.91$, $p<0.0001)$ and of those dispersed by birds $(F=4.51, p<0.0017)$ and by wind $(F=3.24$, $p<0.0154$; Table 2). All other introduction pathways and dispersal modes (strategies) did not differ significantly between the sampling dates at $p<0.05$.

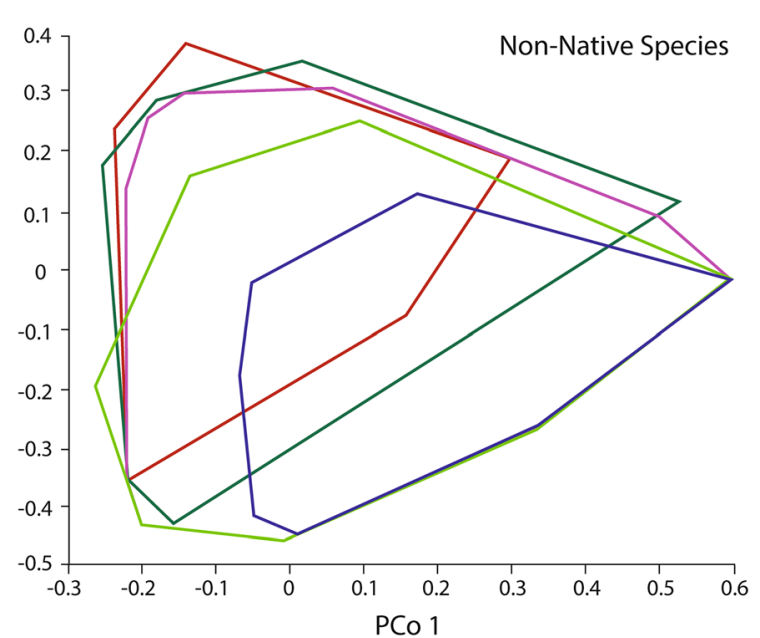

sampling dates. For the ordination, we used the Jaccard dissimilarity coefficient for presence and absence data

\section{Discussion}

Patterns of species richness

Despite the major environmental changes that have taken place in the surrounding metropolitan area, i.e. the progressive increase in urbanization, and the constant removal of vegetation resulting from management procedures, the overall woody plant diversity of the heritage sites in Rome has not changed significantly in the last 70 years. By contrast, the floristic composition has changed, with a decline in the richness of native species and an increase in the richness of non-native species. Moreover, this trend has been associated with a significant increase in those traits (e.g. size) that allow the flora to inflict more damage on monuments. 
Table 2 Mean values for plant height, hazard index (see text) and relative proportion of trees and shrubs, relative proportion of non-native ornamental species and relative proportion of bird-dispersed and wind-dispersed non-native species for the five sampling dates investigated in this study

\begin{tabular}{|c|c|c|c|c|c|}
\hline & 1950 & 1990 & 1995 & 2005 & 2019 \\
\hline \multicolumn{6}{|l|}{ All species (native and non-native) } \\
\hline Maximum plant height (m) & $5.342^{\mathbf{a}}$ & $5.856^{\mathbf{a b}}$ & $6.551^{\text {bc }}$ & $7.609^{\text {cd }}$ & $8.469^{d}$ \\
\hline Hazard Index [1-10] & $4.403^{\mathrm{a}}$ & $4.576^{\mathbf{a b}}$ & $4.781^{\mathbf{b c}}$ & $5.095^{\mathrm{cd}}$ & $5.347^{\mathbf{d}}$ \\
\hline Relative proportion of trees $(\%)$ & $5.758^{\mathbf{a}}$ & $11.351^{\mathbf{b}}$ & $14.877^{\mathbf{b}}$ & $23.818^{\mathrm{c}}$ & $31.751^{\mathrm{c}}$ \\
\hline Relative proportion of shrubs $(\%)$ & $42.015^{\mathbf{a}}$ & $35.064^{\mathrm{ab}}$ & $34.525^{\mathbf{b}}$ & $30.887^{\mathbf{b}}$ & $26.871^{\mathbf{b}}$ \\
\hline \multicolumn{6}{|l|}{ Non-native species only } \\
\hline Relative proportion of ornamental species (\%) & $63.333^{\mathbf{a}}$ & $69.880^{\mathbf{b}}$ & $73.684^{\mathbf{b}}$ & $78.035^{\mathbf{b}}$ & $77.679^{\mathbf{b}}$ \\
\hline Relative proportion of bird-dispersed species (\%) & $20^{\mathbf{a}}$ & $25.301^{\mathbf{a b}}$ & $28.070^{\mathbf{a b}}$ & $32.948^{\mathbf{b}}$ & $33.928^{\mathbf{b}}$ \\
\hline Relative proportion of wind-dispersed species (\%) & $36.667^{\mathbf{a}}$ & $42.168^{\mathrm{a}}$ & $42.982^{\mathbf{a b}}$ & $44.508^{\mathbf{a b}}$ & $42.411^{\mathbf{a b}}$ \\
\hline
\end{tabular}

Pairwise comparisons were performed using one-way permutational ANOVA ( 9999 permutations). For each variable, different letters indicate significant statistical differences in the pairwise comparisons at $p<0.05$. Holm-adjusted data for multiple comparisons

The results in Table 1 and Fig. 2 show that native and non-native woody species have responded in contrasting ways to the environmental changes that have occurred in the city since the 1940 s and to direct management activities. A decrease in native plant species diversity associated with an increase in nonnative plant species diversity along with increasing urbanisation is a well-known pattern that has been reported both in Rome (Celesti-Grapow et al. 2006) and in other cities in the world (Sukopp 2004; Kühn and Klotz 2006; Zhao et al. 2006; Aronson et al. 2015; Štajerová et al. 2017).

The loss of native woody species was somewhat predictable in our study sites, as it is related not only to the densification of the surrounding urban matrix but also to the continual clearing of the walls for management purposes. The vegetation that colonized the sites was repeatedly removed in the years in which we conducted our surveys, particularly over the last two decades, as part of standard management procedures aimed at the conservation of the monuments and at removing vegetation to allow visitors to gain a better view of them (SABAP 2020).

Greater management efforts and the environmental changes that have taken place in the city appear instead to have had a positive effect on the non-native woody flora, whose species diversity has increased since the 1940s. The overall increase in non-native species richness over time and/or along a gradient of increasing human impact is a well-known trend in urban and human-made habitats (Pyšek 1998; Pyšek et al 2010a), where the establishment and spread of the introduced flora are promoted by disturbance and by the widespread availability of propagules from cultivated plants (Pyšek et al. 2010b; Kowarik 2011; Gaertner et al. 2016; Cadotte et al. 2017; Kühn et al. 2017). This increase is, however, a new finding in our study area. Although some studies have previously reported the presence of a few particularly harmful non-native species, such as Ailanthus altissima and Robinia pseudacacia, thereby highlighting the fact that some non-native trees are potentially detrimental to the monuments and recommending that they be monitored and controlled (Celesti and Blasi 2004; Caneva et al. 2009), such cases were considered to be sporadic. Until quite recently non-native plant species were not reported to be establishing successfully on ancient monuments and were thus considered to play a minor role in the flora on ruins where native plants have always thrived. Indeed, culturally important sites have generally been considered hot spots of native species diversity (Ricotta et al. 2001), refuges for local rare or endemic species and important sites for the conservation of natural vegetation, especially within cities (Minissale and Sciandrello 2017; Gopal et al. 2019). This increase undoubtedly constitutes an alarming threat to the conservation of monuments and possibly even to the conservation of the city's biodiversity. 
Changes in species life form, size and deteriogen potential

Management efforts are probably one of the main causes underlying the relative decrease in shrub species in the period considered (Table 2). The shrub species that have declined most belong to the Mediterranean natural maquis, i.e. the evergreen shrub vegetation of the Mediterranean region. Similarly, when Caneva et al. (2003) compared the lists of the flora of the Colosseum published over the past four centuries, they found a general decrease in the numbers of native shrubs species of Mediterranean maquis, especially in those belonging to the most mature stages of succession that were colonizing the horizontal top of walls and ruins.

It is remarkable that the proportion of dwarf shrubs in the flora has not changed significantly over time. The vast majority of these species are evergreen native plants from natural rocky habitats, such as the caper (Capparis spinosa L., Fig. 1), that have found an analogue to their natural habitat in the city walls (Lundholm and Richardson 2010; Kowarik et al. 2016). These species are the most typical components of the wall flora of Rome, where they are widespread and abundant in the sites we analysed and on ancient walls throughout the city centre.

The relative proportions of trees have, on the other hand, steadily increased over time (Table 2). This is an unusual pattern in the wall flora. Native trees had until recently always been very scarce on walls even though some, such as laurel (Laurus nobilis L.) and Holm oak (Quercus ilex L.), had been extensively planted in the city centre and thus provided abundant sources of seeds.

The increase in the number of trees in the study area as well as the higher number of woody species with a greater deteriogen potential over time are trends that should arouse concern. In urban areas, trees have been shown to exert serious impacts on buildings and infrastructures (Fig. 1) owing to their great weight, extensive root systems and, most importantly, their secondary diametric root growth, which can seriously damage paved surfaces, walls and monuments and require costly measures if they are to be eradicated (Potgieter et al. 2019b).

The important role of tall alien trees as the invasive species that exert the most negative impacts in urban contexts has been repeatedly highlighted (McLean et al. 2017; Potgieter et al. 2019a). Indeed large size, and specifically plant height, is one of the major predictors of the capacity of non-native plants to spread and become invasive (Pyšek et al. 2012) as well as one of the main reasons for why non-native trees are among the most widespread and harmful invasive species worldwide (Bucharova and van Kleunen 2009; Richardson and Rejmánek 2011; Pyšek et al. 2014; Rejmánek 2014).

Changes in the introduction history and dispersal strategies of the non-native flora

The preference of humans for peculiar plant traits has caused an increase in the proportion of non-native trees in urban areas following the introduction of ornamental species that have escaped from cultivation (Potgieter et al. 2017). In recent years, several studies have highlighted the importance of the introduction pathways and of the dispersal strategies on the invasion success of non-native species, (Essl et al. 2015; Pergl et al. 2017; Sádlo et al. 2018), and in particular trees (Donaldson et al. 2014). In our study area, the proportion of ornamentals in the non-native flora grew over time, thus confirming the importance of ornamental horticulture as the main introduction pathway of invasive plants (Dehnen-Schmutz et al. 2007; Hulme et al. 2018; van Kleunen et al. 2018), particularly in urban areas (Kowarik 2005; Kowarik et al. 2013; McLean et al. 2017; Padayachee et al. 2017; Petř́k et al. 2019).

As regards the dispersal modes, the proportion of trees dispersed by birds and wind in the flora within the study area also grew over time. In urban areas, anemochory and ornithochory are common dispersal modes (Lososová et al. 2006), and fruit type was found to be related to the success of woody non-native plants (Aronson et al. 2007). Indeed, wind- and birddispersed propagules are efficiently transported to the highest parts of monuments, where control measures such as mowing are both difficult and costly. A case in point is the Colosseum, which is $57 \mathrm{~m}$ high and whose uppermost sections have been cleared of plants only thanks to exceptional restoration sponsorships (Caneva et al. 2003; Tod's for Colosseum 2017).

Although human-mediated dispersal can play an important role in the spread of plants in man-made sites, the species composition in the area considered in this study is unlikely to have been affected by visitors 
to the sites because humans do not act as dispersal vectors of the woody species we analysed, as instead happens for some herbaceous species that are transported, for example, on the shoes or clothing of humans.

Most widespread and emerging species and management challenges

The aforementioned trends are confirmed by findings showing that within our study area the most relevant non-native species, i.e. those whose numbers have increased most since the 1940s and that are currently most widespread on monuments, are all plants introduced as ornamentals and dispersed by wind or birds. These species are prevalently trees, such as Acer negundo, Ailanthus altissima (Fig. 1), Ligustrum lucidum, Platanus hispanica and Robinia pseudoacacia, that have been planted along roads and in city parks. As propagule pressure and planting intensity are important correlates of invasion success of non-native species, particularly of trees (Pyšek et al. 2009; Feng et al. 2016), these findings may prove useful for the prioritization of management efforts in cities and for the management of urban green spaces (Potgieter et al. 2018), as they highlight the need to avoid using ornamentals of wind- and bird-dispersed trees that were shown both to be invasive and to have the potential to grow on and to deteriorate man-made constructions i.e., Ailanthus altissima, Acer negundo and Ligustrum lucidum.

Among the most relevant non-native plants there are also a few ornamental vine species, the most rapidly increasing and widespread of which is Parthenocissus quinquefolia; these species tend, however, to be planted in private residential gardens, where they are widely used as covering for shelters and fences. Indeed, climbing plants are very common in densely built-up urban areas because they take up little room in small courtyards and they grow well in pots on roof gardens. When they escape cultivation, some climbers are considered to severely threaten the conservation of ancient monuments because they can establish successfully on walls and form a dense cover. However, the impact of climbers on the conservation of monuments is still debated: while they are blamed for damaging monuments, some are also considered to provide a certain degree of protection for the remains they cover (Viles et al. 2011; Kowarik et al. 2016; Bartoli et al. 2017).

Although most of the widespread species mentioned above are widely cultivated throughout the metropolitan area of Rome, they are neither common nor abundant in the wild. The only widespread invasive species that grow spontaneously in the city are Ailanthus altissima and Robinia pseudoacacia (Celesti-Grapow 1995). These trees are also the two most widespread woody species in the non-native flora of Italy, with Ailanthus altissima being the only woody species classified as invasive in every Italian administrative region (Galasso et al. 2018).

Ailanthus altissima (Fig. 1) is a tree that typically invades urban areas and has become one of the most common alien trees in urban land in Europe as well as other countries in the rest of the world (Kowarik and Säumel 2007; Kowarik et al. 2013; Sladonja et al. 2015; Sladonja and Poljuha 2018).

In the sites we analysed, the presence of Ailanthus altissima has constantly increased over the decades, from five sites in 1950, to 11 in 1990, 13 in 1995, 19 in 2005 and 22 currently. Moreover, unlike most other non-native trees, which are usually represented by a single or few individuals, Ailanthus altissima often becomes very abundant and reach high cover on the monuments. In Rome, this tree is found throughout the metropolitan area, where it forms dense stands in different habitat types, preferentially colonising abandoned land and roadsides. Ailanthus altissima is the only non-native species of the flora in Rome to be acknowledged to exert a highly significant negative impact (Celesti-Grapow et al. 2013), by infrastructural damage resulting from an aggressive root system (Almeida et al. 1994; Motti and Stinca 2011; Casella and Vurro 2013), particularly on the city's historical heritage, i.e. ancient monuments and archaeological remains.

The main features that make this early successional tree so successful are its adaptation to wall habitats, tolerance to urban conditions, efficient reproduction and dispersal and difficult management (Kowarik and Säumel 2007; Constán-Nava et al. 2010; Badalamenti et al. 2012; Wickert et al. 2017). Its winged, winddispersed samaras are efficiently transported to the highest parts of the monuments from where it can further spread vegetatively. Standard management procedures, which mainly consists in cutting the plant at its base, stimulate resprouting and increase overall 
density of Ailanthus altissima stands (Burch and Zedaker 2003).

The impacts of this species in a wide range of habitats have resulted in it recently being added to the European Union List of Invasive Alien Species of Union concern (EU Regulation 2019/1262). This list includes species that are subject to restrictions and measures set out in the European Union Regulation on Invasive Alien Species (EU Regulation 1143/2014, European Union 2014) and is the core instrument of the Regulation (Genovesi et al. 2015). Despite this, scientific evidence on the impacts of Ailanthus altissima is still scarce. Our results confirm the need (i) to carry out more thorough investigations into the impacts of this species, which is considered one of the main flagship invaders in Europe (Nentwig et al. 2018), and (ii) to include the control of Ailanthus altissima among the priorities in management actions in urban systems not only at the local and national scales but in other countries worldwide.

\section{Management challenges, future research and conclusions}

Our results show that the invasion of non-native harmful species has steadily progressed in recent decades despite management efforts aimed at suppressing the vegetation covering the monuments. The recent spread of some invasive trees on heritage sites represents a new finding and an emerging challenge for the conservation of such areas.

This is a highly complex problem, particularly when these species are located in urban systems. In addition to the conflict of values that typically affects urban green spaces (Pickett et al. 2001; Kowarik 2011; Gaertner et al. 2017b; Saloman Cavin and Kull 2017; Potgieter et al. 2019b), such as the need to choose between urban development and nature conservation (Dearborn and Kark 2010) or to decide whether to use native or non-native species (Sjöman et al. 2016), heritage sites introduce further specific challenges, such as the need to choose between the protection of monuments and the conservation of biodiversity.

Indeed, some monumental areas are not only important components of the urban biodiversity but are also of considerable global value (e.g. world cultural heritage sites) as well as of great national socio-economic importance for a number of sectors (e.g. the tourist industry).

Further open questions in the current debate on the management of plants on heritage sites regard whether some species, rather than being a cause of biodeterioration, actually provide a certain degree of bioprotection for monuments by acting as a barrier against weathering and thermal stress and by reducing erosion (Viles et al. 2011; Kowarik et al. 2016; Salvadori and Casanova 2016). It should also be borne in mind that some management actions can inflict considerable damage on monuments. This is not, however, the case in our study area, in which the removal methods are aimed at hindering the development of a dense plant cover and the succession towards more mature stages and are, consequently, mainly limited to mowing and cutting at the base of the plant.

Another issue that is related to invasive species on heritage sites is the cultural connections that people have with plants, particularly in cities (Gaertner et al. 2016, 2017a). Examples include tensions with the local inhabitants that often arise when trees are to be removed (Dickie et al. 2014) and the positive perception of inhabitants who may appreciate the iconic value of the plants covering the monuments.

All these reasons also show that management of invasive plants in culturally protected sites, especially when located in urban areas, is considerably more complex than that of invasive plants in agricultural areas, where most traditional management methods have originated (Pearson and Ortega 2009), and cannot consist in the mere removal of the target species, that may even result in an increase of secondary invaders (see Pearson et al. 2016).

Despite the complexity of this problem, we believe that the expansion of invasive species needs to be urgently addressed because it shows no signs of slowing. Further research and interventions, including specific monitoring and control campaigns, need to be implemented to prevent future invasions. New management strategies need to be developed by integrating multidisciplinary approaches that take into account the wide range of interests involved in heritage sites, including first and foremost the conservation of the monuments themselves. All in all, we believe that culturally protected sites provide an opportunity to gain new insights into the management of plant invasions, particularly in urban systems. 
Acknowledgements We wish to express our gratitude to the late Prof. Bruno Anzalone, who provided us with valuable information on his work on the flora of the walls of Rome. We are also grateful to the two anonymous reviewers for their insightful suggestions, which we feel have greatly improved the paper.

Funding Open access funding provided by Università degli Studi di Roma La Sapienza within the CRUI-CARE Agreement. The authors have no relevant financial or non-financial interests to disclose.

Data availability The datasets generated during and/or analysed during the current study are available from the corresponding author on reasonable request.

\section{Compliance with ethical standards}

Conflict of interest The authors have no conflicts of interest to declare that are relevant to the content of this article.

Open Access This article is licensed under a Creative Commons Attribution 4.0 International License, which permits use, sharing, adaptation, distribution and reproduction in any medium or format, as long as you give appropriate credit to the original author(s) and the source, provide a link to the Creative Commons licence, and indicate if changes were made. The images or other third party material in this article are included in the article's Creative Commons licence, unless indicated otherwise in a credit line to the material. If material is not included in the article's Creative Commons licence and your intended use is not permitted by statutory regulation or exceeds the permitted use, you will need to obtain permission directly from the copyright holder. To view a copy of this licence, visit http://creativecommons.org/licenses/by/4.0/.

\section{References}

Almeida MT, Mouga T, Barracosa P (1994) The weathering ability of higher plants. The case of Ailanthus altissima (Miller) Swingle. Int Biodeterior Biodegrad 33:333-343. https://doi.org/10.1016/0964-8305(94)90011-6

Anderson MJ (2001) A new method for non-parametric multivariate analysis of variance. Austral Ecol 26:32-46. https:// doi.org/10.1111/j.1442-9993.2001.01070.pp.x

Anzalone B (1951) Flora e vegetazione dei muri di Roma. Ann Bot 23:393-497

Aronson M, Handel SN, Clemants SE (2007) Fruit type, life form and origin determine the success of woody plant invaders in an urban landscape. Biol Invasions 9:465-475. https://doi.org/10.1007/s10530-006-9053-1

Aronson MFJ, Handel SN, La Puma IP, Clemants SE (2015) Urbanization promotes non-native woody species and diverse plant assemblages in the New York metropolitan region. Urban Ecosyst 18:31-45. https://doi.org/10.1007/ s11252-014-0382-z

Badalamenti E, Barone E, Pasta S, Sala G, La Mantia T (2012) Ailanthus altissima (Mill.) Swingle (Simaroubaceae) in
Sicily and historical remarks on its introduction in Italy. Nat Siciliano 36:117-164

Bartoli F, Romiti F, Caneva G (2017) Aggressiveness of Hedera helix L. growing on monuments: evaluation in Roman archaeological sites and guidelines for a general methodological approach. Plant Biosyst 151:866-877. https://doi. org/10.1080/11263504.2016.1218969

Bhagwat SA, Rutte C (2006) Sacred groves: potential for biodiversity management. Front Ecol Environ 4:519-524

Bucharova A, Van Kleunen M (2009) Introduction history and species characteristics partly explain naturalization success of North American woody species in Europe. J Ecol 97:230-238. https://doi.org/10.1111/j.1365-2745.2008. 01469.x

Burch PL, Zedaker SM (2003) Removing the invasive tree Ailanthus altissima and restoring natural cover. J Arboric 29:18-24

Cadotte MW, Yasui SLE, Livingstone S, MacIvor JS (2017) Are urban systems beneficial, detrimental, or indifferent for biological invasion? Biol Invasions 19:3489-3503. https:// doi.org/10.1007/s10530-017-1586-y

Caneva G, Pacini A, Celesti Grapow L, Ceschin S (2003) The Colosseum's use and state of abandonment as analysed through its flora. Int Biodeterior Biodegrad 51:211-219. https://doi.org/10.1016/S0964-8305(02)00173-7

Caneva G, Ceschin S, De Marco G (2006) Mapping the risk of damage from tree roots for the conservation of archaeological sites: the case of the Domus Aurea, Rome. Conserv Manag Archaeol Sites 7:163-170. https://doi.org/10.1179/ 135050306793137403

Caneva G, Nugari MP, Salvadori O (eds) (2008) Plant biology for cultural heritage: biodeterioration and conservation. Getty Publications, Los Angeles

Caneva G, Galotta G, Cancellieri L, Savo V (2009) Tree roots and damages in the Jewish catacombs of Villa Torlonia (Roma). J Cult Herit 10:53-62. https://doi.org/10.1016/j. culher.2008.04.005

Capotorti G, Del Vico E, Lattanzi E et al (2013) Exploring biodiversity in a metropolitan area in the Mediterranean region: the urban and suburban flora of Rome (Italy). Plant Biosyst 147:174-185. https://doi.org/10.1080/11263504. 2013.771715

Casella F, Vurro M (2013) Ailanthus altissima (tree of heaven): spread and harmfulness in a case-study urban area. Arboric J 35:172-181

CBD (2014) Pathways of introduction of invasive species, their prioritization and management; UNEP/CBD/SBSTTA/18/ 9/Add.1. https://www.cbd.int/doc/meetings/sbstta/sbstta18/official/sbstta-18-09-add1-en.pdf

Celesti-Grapow L (1995) Atlas of the flora of Rome. Comune di Roma, Rome

Celesti-Grapow L, Blasi C (2004) The role of Alien and native weeds in the deterioration of archaeological remains in Italy 1. Weed Technol 18:1508-1513. https://doi.org/10. 1614/0890-037x(2004)018[1508:troaan]2.0.co;2

Celesti-Grapow L, Pyšek P, Jarošík V, Blasi C (2006) Determinants of native and alien species richness in the urban flora of Rome. Divers Distrib 12:490-501. https://doi.org/ 10.1111/j.1366-9516.2006.00282.x

Celesti-Grapow L, Capotorti G, Del Vico E et al (2013) The vascular flora of Rome. Plant Biosyst 147:1059-1087 
Ceschin S, Bartoli F, Salerno G et al (2016) Natural habitats of typical plants growing on ruins of Roman archaeological sites (Rome, Italy). Plant Biosyst 150:866-875. https://doi. org/10.1080/11263504.2014.990536

Cicinelli E, Salerno G, Caneva G (2018) An assessment methodology to combine the preservation of biodiversity and cultural heritage: the San Vincenzo al Volturno historical site (Molise, Italy). Biodivers Conserv 27:1073-1093. https://doi.org/10.1007/s10531-017-1480$\mathrm{z}$

Cicinelli E, Benelli F, Bartoli F et al (2020) Trends of plant communities growing on the Etruscan tombs (Cerveteri, Italy) related to different management practices. Plant Biosyst 154:158-164. https://doi.org/10.1080/11263504. 2019.1578286

Constán-Nava S, Bonet A, Pastor E, Lledó MJ (2010) Longterm control of the invasive tree Ailanthus altissima: insights from Mediterranean protected forests. For Ecol Manage 260:1058-1064. https://doi.org/10.1016/j.foreco. 2010.06.030

Cutler DF, Richardson IBK (1989) Tree roots and buildings, 2nd edn. Longman Scientific \& Technical, Harlow

Dearborn DC, Kark S (2010) Motivations for conserving urban biodiversity. Conserv Biol 24:432-440. https://doi.org/10. 1111/j.1523-1739.2009.01328.x

Dehnen-Schmutz K, Touza J, Perrings C, Williamson M (2007) The horticultural trade and ornamental plant invasions in Britain. Conserv Biol 21:224-231. https://doi.org/10.1111/ j.1523-1739.2006.00538.x

Dickie IA, Bennett BM, Burrows LE et al (2014) Conflicting values: ecosystem services and invasive tree management. Biol Invasions 16:705-719. https://doi.org/10.1007/ s10530-013-0609-6

Donaldson JE, Hui C, Richardson DM et al (2014) Invasion trajectory of alien trees: the role of introduction pathway and planting history. Glob Chang Biol 20:1527-1537. https://doi.org/10.1111/gcb.12486

Essl F, Bacher S, Blackburn TM et al (2015) Crossing frontiers in tackling pathways of biological invasions. Bioscience 65:769-782. https://doi.org/10.1093/biosci/biv082

European Union (2014) Regulation (EU) No 1143/2014 of the European Parliament and of the Council of 22 October 2014 on the prevention and management of the introduction and spread of invasive alien species. OJ L 317 (4.11.2014), 35-55

Feng Y, Maurel N, Wang Z et al (2016) Introduction history, climatic suitability, native range size, species traits and their interactions explain establishment of Chinese woody species in Europe. Glob Ecol Biogeogr 25:1356-1366. https://doi.org/10.1111/geb.12497

Frascaroli F, Bhagwat S, Guarino R et al (2016) Shrines in Central Italy conserve plant diversity and large trees. Ambio 45:468-479. https://doi.org/10.1007/s13280-0150738-5

Frosch B, Deil U (2011) Forest vegetation on sacred sites of the Tangier Peninsula (NW Morocco)-discussed in a SWMediterranean context. Phytocoenologia 41:153-181. https://doi.org/10.1127/0340-269X/2011/0041-0503

Gaertner M, Larson BMH, Irlich UM et al (2016) Managing invasive species in cities: a framework from Cape Town,
South Africa? Landsc Urban Plan 151:1-9. https://doi.org/ 10.1016/j.landurbplan.2016.03.010

Gaertner M, Novoa A, Fried J, Richardson DM (2017a) Managing invasive species in cities: a decision support framework applied to Cape Town. Biol Invasions 19:3707-3723. https://doi.org/10.1007/s10530-017-1587$\mathrm{x}$

Gaertner M, Wilson JRU, Cadotte MW et al (2017b) Non-native species in urban environments: patterns, processes, impacts and challenges. Biol Invasions 19:3461-3469. https://doi. org/10.1007/s10530-017-1598-7

Galasso G, Conti F, Peruzzi L et al (2018) An updated checklist of the vascular flora alien to Italy. Plant Biosyst 152:556-592. https://doi.org/10.1080/11263504.2018. 1441197

Gao H, Ouyang Z, Chen S, van Koppen CSA (2013) Role of culturally protected forests in biodiversity conservation in Southeast China. Biodivers Conserv 22:531-544. https:// doi.org/10.1007/s10531-012-0427-7

Genovesi P, Carboneras C, Vilà M, Walton P (2015) EU adopts innovative legislation on invasive species: a step towards a global response to biological invasions? Biol Invasions 17:1307-1311. https://doi.org/10.1007/s10530-014-08178

Gopal D, von der Lippe M, Kowarik I (2019) Sacred sites, biodiversity and urbanization in an Indian megacity. Urban Ecosyst 22:161-172. https://doi.org/10.1007/s11252-0180804-4

Hulme PE, Bacher S, Kenis M et al (2008) Grasping at the routes of biological invasions: a framework for integrating pathways into policy. J Appl Ecol 45:403-414. https://doi.org/ 10.1111/j.1365-2664.2007.01442.x

Hulme PE, Brundu G, Carboni M et al (2018) Integrating invasive species policies across ornamental horticulture supply chains to prevent plant invasions. J Appl Ecol 55:92-98. https://doi.org/10.1111/1365-2664.12953

Ives CD, Lentini PE, Threlfall CG et al (2016) Cities are hotspots for threatened species. Glob Ecol Biogeogr 25:117-126. https://doi.org/10.1111/geb.12404

Jackson W, Ormsby A (2017) Urban sacred natural sites—a call for research. Urban Ecosyst 20:675-681. https://doi.org/ 10.1007/s11252-016-0623-4

Kleyer M, Bekker RM, Knevel IC et al (2008) The LEDA Traitbase: a database of life-history traits of the Northwest European flora. J Ecol 96:1266-1274. https://doi.org/10. $1111 / \mathrm{j} .1365-2745.2008 .01430 . x$

Kowarik I (2005) Urban ornamentals escaped from cultivation. In: Gressel J (ed) Crop ferality and volunteerism. CRC Press, Boca Raton, pp 97-121

Kowarik I (2011) Novel urban ecosystems, biodiversity, and conservation. Environ Pollut 159:1974-1983. https://doi. org/10.1016/j.envpol.2011.02.022

Kowarik I, Säumel I (2007) Biological flora of Central Europe: Ailanthus altissima (Mill.) Swingle. Perspect Plant Ecol Evol Syst 8:207-237. https://doi.org/10.1016/j.ppees. 2007.03.002

Kowarik I, Von Der Lippe M, Cierjacks A (2013) Prevalence of alien versus native species of woody plants in Berlin differs between habitats and at different scales. Preslia 85:113-132 
Kowarik I, Buchholz S, von der Lippe M, Seitz B (2016) Biodiversity functions of urban cemeteries: evidence from one of the largest Jewish cemeteries in Europe. Urban Forestry and Urban Greening 19:68-78

Kühn I, Klotz S (2006) Urbanization and homogenizationComparing the floras of urban and rural areas in Germany. Biol Conserv 127:292-300

Kühn I, Wolf J, Schneider A (2017) Is there an urban effect in alien plant invasions? Biol Invasions 19:3505-3513. https://doi.org/10.1007/s10530-017-1591-1

Latombe G, Pyšek P, Jeschke JM et al (2017) A vision for global monitoring of biological invasions. Biol Conserv 213:295-308. https://doi.org/10.1016/j.biocon.2016.06. 013

Legendre P, Legendre L (1998) Numerical ecology. Elsevier, Amsterdam

Lisci M, Pacini E (1993) Plants growing on the walls of Italian towns. 1 sites and distribution. Phyton 33:15-26

Lisci M, Monte M, Pacini E (2003) Lichens and higher plants on stone: a review. Int Biodeterior Biodegrad 51:1-17. https:// doi.org/10.1016/S0964-8305(02)00071-9

Lososová Z, Chytrý M, Kühn I et al (2006) Patterns of plant traits in annual vegetation of man-made habitats in central Europe. Perspect Plant Ecol Evol Syst 8:69-81. https://doi. org/10.1016/j.ppees.2006.07.001

Lundholm JT, Richardson PJ (2010) Habitat analogues for reconciliation ecology in urban and industrial environments. J Appl Ecol 47:966-975. https://doi.org/10.1111/j. 1365-2664.2010.01857.x

McArdle BH, Anderson MJ (2001) Fitting multivariate models to community data: a comment on distance-based redundancy analysis. Ecology 82:290-297

McLean P, Gallien L, Wilson JRU et al (2017) Small urban centres as launching sites for plant invasions in natural areas: insights from South Africa. Biol Invasions 19:3541-3555. https://doi.org/10.1007/s10530-017-16004

Minissale P, Sciandrello S (2017) The Wild Vascular Flora of the Archaeological Park of Neapolis in Syracuse and Surrounding Areas (Sicily, Italy). Biodivers J 8(1):87-104

Motti R, Bonanomi G (2018) Vascular plant colonisation of four castles in southern Italy: effects of substrate bioreceptivity, local environment factors and current management. Int Biodeterior Biodegrad 133:26-33. https://doi.org/10.1016/ j.ibiod.2018.06.004

Motti R, Stinca A (2011) Analysis of the biodeteriogenic vascular flora at the Royal Palace of Portici in southern Italy. Int Biodeterior Biodegrad 65:1256-1265. https://doi.org/ 10.1016/j.ibiod.2010.03.010

Nentwig W, Bacher S, Kumschick S et al (2018) More than "100 worst" alien species in Europe. Biol Invasions 20:1611-1621. https://doi.org/10.1007/s10530-017-16516

Nielsen AB, van den Bosch M, Maruthaveeran S, van den Bosch CK (2014) Species richness in urban parks and its drivers: a review of empirical evidence. Urban Ecosyst 17:305-327. https://doi.org/10.1007/s11252-013-0316-1

Padayachee AL, Irlich UM, Faulkner KT et al (2017) How do invasive species travel to and through urban environments? Biol Invasions 19:3557-3570. https://doi.org/10.1007/ s10530-017-1596-9
Pearson DE, Ortega YK (2009) Managing invasive plants in natural areas: moving beyond weed control. In: Kingely RV (ed) Weeds: management, economic impacts and biology. Nova Science Publishers, New York

Pearson DE, Ortega YK, Runyon JB, Butler JL (2016) Secondary invasion: the bane of weed management. Biol Conserv 197:8-17. https://doi.org/10.1016/j.biocon.2016. 02.029

Pérez-Harguindeguy N, Díaz S, Garnier E et al (2013) New handbook for standardised measurement of plant functional traits worldwide. Aust J Bot 61:167-234. https://doi. org/10.1071/BT12225

Pergl J, Pyšek P, Bacher S et al (2017) Troubling travellers: are ecologically harmful alien species associated with particular introduction pathways? NeoBiota 32:1-20. https://doi. org/10.3897/neobiota.32.10199

Petrrík P, Sádlo J, Hejda M et al (2019) Composition patterns of ornamental flora in the Czech Republic. NeoBiota 52:87-109. https://doi.org/10.3897/neobiota.52.39260

Pickett STA, Cadenasso ML, Grove JM, Nilon CH (2001) Urban ecological systems: linking terrestrial ecological, physical, and socioeconomic components of metropolitan areas. Annu Rev Ecol Syst 32:127-157. https://doi.org/10.1146/ annurev.ecolsys.32.081501.114012

Pignatti S (2017-2019) Flora d'Italia. Vol 1-4. Edagricole, Milano

Planchuelo G, von Der Lippe M, Kowarik I (2019) Untangling the role of urban ecosystems as habitats for endangered plant species. Landsc Urban Plan 189:320-334. https://doi. org/10.1016/j.landurbplan.2019.05.007

Potgieter LJ, Gaertner M, Kueffer C et al (2017) Alien plants as mediators of ecosystem services and disservices in urban systems: a global review. Biol Invasions 19:3571-3588. https://doi.org/10.1007/s10530-017-1589-8

Potgieter LJ, Gaertner M, Irlich UM, O'Farrell PJ, Stafford L, Vogt H, Richardson DM (2018) Managing urban plant invasions: a multi-criteria prioritization approach. Environ Manag 62:1168-1185. https://doi.org/10.1007/s00267018-1088-4

Potgieter LJ, Gaertner M, O'Farrell PJ, Richardson DM (2019a) A fine-scale assessment of the ecosystem service-disservice dichotomy in the context of urban ecosystems affected by alien plant invasions. Ecosyst 6:1-16. https://doi.org/10. 1186/s40663-019-0200-4

Potgieter LJ, Gaertner M, O'Farrell PJ, Richardson DM (2019b) Perceptions of impact: Invasive alien plants in the urban environment. J Environ Manage 229:76-87. https://doi. org/10.1016/j.jenvman.2018.05.080

Pyšek P (1998) Alien and native species in Central European urban floras: a quantitative comparison. J Biogeogr 25:155-163

Pyšek P, Bacher S, Chytrý M et al (2010a) Contrasting patterns in the invasions of European terrestrial and freshwater habitats by alien plants, insects and vertebrates. Glob Ecol Biogeogr 19:317-331. https://doi.org/10.1111/j.14668238.2009.00514.x

Pyšek P, Jarošík V, Hulme PE et al (2010b) Disentangling the role of environmental and human pressures on biological invasions across Europe. Proc Natl Acad Sci USA 107:12157-12162. https://doi.org/10.1073/pnas.100231 4107 
Pyšek P, Jarošík V, Hulme PE et al (2012) A global assessment of invasive plant impacts on resident species, communities and ecosystems: the interaction of impact measures, invading species' traits and environment. Glob Chang Biol 18:1725-1737. https://doi.org/10.1111/j.1365-2486.2011. 02636.x

Pyšek P, Jarošík V, Pergl J et al (2014) Temperate trees and shrubs as global invaders: the relationship between invasiveness and native distribution depends on biological traits. Biol Invasions 16:577-589. https://doi.org/10.1007/ s10530-013-0600-2

Pyšek P, Křivánek M, Jarošik V (2009) Planting intensity, residence time, and species traits determine invasion success of alien woody species. Ecology 90:2734-2744. https:// doi.org/10.1890/08-0857.1

Raunkiær C (1905) Types biologiques pour la géographie botanique. Oversigt over Det Kongelige Danske Videnskabernes Selskabs Forhandlinger 347-438

Rejmánek M (2014) Invasive trees and shrubs: Where do they come from and what we should expect in the future? Biol Invasions 16:483-498. https://doi.org/10.1007/s10530013-0603-z

Richardson DM, Rejmánek M (2011) Trees and shrubs as invasive alien species-a global review. Divers Distrib 17:788-809. https://doi.org/10.1111/j.1472-4642.2011. 00782.x

Ricotta C, Celesti-Grapow L, Avena GC, Blasi C (2001) Topological analysis of the spatial distribution of plant species richness across the city of Rome (Italy) with the echelon approach. Landsc Urban Plan 57:69-76

Rupprecht CDD, Byrne JA (2014) Informal urban green-space: comparison of quantity and characteristics in Brisbane, Australia and Sapporo, Japan. PLoS ONE 9:1-13. https:// doi.org/10.1371/journal.pone.0099784

SABAP (2020). Soprintendenza Archeologia, Belle Arti e Paesaggio per l'area metropolitana di Roma, la provincia di Viterbo e l'Etruria meridionale http://www.sabap-rm-met. beniculturali.it

Sádlo J, Chytrý M, Pergl J, Pyšek P (2018) Plant dispersal strategies: A new classification based on the multiple dispersal modes of individual species. Preslia 90:1-22. https:// doi.org/10.23855/preslia.2018.001

Saloman Cavin J, Kull CA (2017) Invasion ecology goes to town: from disdain to sympathy. Biol Invasions 19:3471-3487. https://doi.org/10.1007/s10530-017-15889

Salvadori O, Casanova A (2016) The role of fungi and lichens in the biodeterioration of stone monuments. Open Conf Proc J 7:39-54. https://doi.org/10.2174/2210289201607020039

Säumel I, Weber F, Kowarik I (2016) Toward livable and healthy urban streets: roadside vegetation provides ecosystem services where people live and move. Environ Sci Policy 62:24-33. https://doi.org/10.1016/j.envsci. 2015.11.012

Seebens H, Blackburn TM, Dyer EE et al (2017) No saturation in the accumulation of alien species worldwide. Nat Commun 8:1-9. https://doi.org/10.1038/ncomms14435

Shwartz A, Muratet A, Simon L, Julliard R (2013) Local and management variables outweigh landscape effects in enhancing the diversity of different taxa in a big metropolis. Biol Conserv 157:285-292. https://doi.org/10. 1016/j.biocon.2012.09.009

Shwartz A, Turbé A, Julliard R et al (2014) Outstanding challenges for urban conservation research and action. Glob Environ Chang 28:39-49. https://doi.org/10.1016/j. gloenvcha.2014.06.002

Signorini MA (1996) L'indice di Pericolosità: un contributo del botanico al controllo della vegetazione infestante nelle aree monumentali. Informatore Botanico Italiano 28:7-14

Sjöman H, Morgenroth J, Sjöman JD et al (2016) Diversification of the urban forest-Can we afford to exclude exotic tree species? Urban Urban Green 18:237-241. https://doi.org/ 10.1016/j.ufug.2016.06.011

Sladonja B, Poljuha D (2018) Citizen science as a tool in biological recording-a case study of Ailanthus altissima Swingle. Forests 9. https://doi.org/10.3390/f901003

Sladonja B, Sušek M, Guillermic J (2015) Review on invasive tree of heaven (Ailanthus altissima (Mill.) Swingle) conflicting values: assessment of its ecosystem services and potential biological threat. Environ Manage 56:1009-1034. https://doi.org/10.1007/s00267-015-05465

Štajerová K, Šmilauer P, Brůna J, Pyšek P (2017) Distribution of invasive plants in urban environment is strongly spatially structured. Landsc Ecol 32:681-692. https://doi.org/10. 1007/s10980-016-0480-9

Sukopp H (2004) Human-caused impact on preserved vegetation. Landsc Urban Plan 68:347-355. https://doi.org/10. 1016/S0169-2046(03)00152-X

Tod's for Colosseum (2017) https://www.tods.com/ww-en/ stories/tods-for-colosseum.html

van Kleunen M, Essl F, Pergl J et al (2018) The changing role of ornamental horticulture in alien plant invasions. Biol Rev 93:1421-1437. https://doi.org/10.1111/brv.12402

van Wilgen BW, Richardson DM (2014) Challenges and tradeoffs in the management of invasive alien trees. Biol Invasions 16:721-734. https://doi.org/10.1007/s10530-0130615-8

Verschuuren B, Wild R, McNeely J, Oviedo G (2010) Sacred natural sites: conserving nature and culture. Earthscan, London

Viles H, Sternberg T, Cathersides A (2011) Is ivy good or bad for historic walls? J Archit Conserv 17:25-41. https://doi. org/10.1080/13556207.2011.10785087

Warscheid T, Braams J (2000) Biodeterioration of stone: a review. Int Biodeterior Biodegrad 46:343-368. https://doi. org/10.1016/S0964-8305(00)00109-8

WHC UNESCO (1990). Historic Centre of Rome, the properties of the Holy See in that city enjoying its extra-territorial rights and San Paolo Fuori le Mural (Italy/Holy See). 14th session of the World Heritage Committee (CONF 004) Decision: CONF 004 VII.B

Wickert KL, O’Neal ES, Davis DD, Kasson MT (2017) Seed production, viability, and reproductive limits of the invasive Ailanthus altissima (tree-of-heaven) within invaded environments. Forests. https://doi.org/10.3390/f8070226

Woods CL, Cardelús CL, Scull P et al (2017) Stone walls and sacred forest conservation in Ethiopia. Biodivers Conserv 26:209-221. https://doi.org/10.1007/s10531-016-1239-y 
Zhao S, Da L, Tang Z et al (2006) Ecological consequences of rapid urban expansion: Shanghai, China. Front Ecol Environ 4:341-346. https://doi.org/10.1890/1540-9295 (2006)004[0341:ECORUE]2.0.CO;2
Publisher's Note Springer Nature remains neutral with regard to jurisdictional claims in published maps and institutional affiliations. 